\title{
WOMEN IN THE AGE OF DOLLARS AND INDIAN CURRENCY - A PERCEPTION INTO SUDHA MURTHY'S DOLLAR BAHU AND MAHA SHWETHA
}

\author{
Ms. T.Sai Mamata \\ Ph.D Research Scholar \\ Andhra Loyola College \\ Vijayawada-8 \\ Email: mamata6566@gmail.com
}

\begin{abstract}
21 st century has witnessed a marvelous development in the fields of science and technology, education, literature, arts and business, but all this was achieved at the cost of degrading human values. All the nations look at India at the dressing attires and orthodox family structures. The world has created a passion for following Indian cultures and traditions. Are Indians preserving and valuing their own culture? It's a million dollar question hanging around every Indian. The present article focuses on the declining human values and attitudes in the modern sophisticated era. Sudha Murthy's two novels Mahashweta and Dollar Bahu make the readers to realize the importance of humanity, despite the domination of money. The two novels are set around the typical south Indian Kannada families. The mental agonies of Anupama in Mahashweta and Vinuta in Dollar Bahu makes one to feel that they are existing in their own families, but unfortunately the traumas are not identified. Sudha Murthy's brilliance in interweaving the characters makes the readers to come out of money-madness and retain their permanent human relations.
\end{abstract}

Key words: Dollars, orthodox family systems, money-madness

It's quite amazing that Indian women are longer confined to kitchens. Indian women set their foot on space challenging their position in the male dominated society. Women have achieved success in the fields of education, politics, business, software and creative writing. The success which women in the $21^{\text {st }}$ century are making is not a simple achievement, but unfortunately there are women who are still considered as dark horses. A newly born child tries his recognition from his kith and kin by a thunderous bawl. Every one attends him, his first seed of identification sprouts up. The gender discrimination slowly makes the male child to dominate by sub- ordinating the female ones. Naturally the suppressed female develops frustration and tries to prove herself. In this process she undergoes a series of humiliations, betrayals making her life miserable. As the modern civilians is it not our duty to consider this issue 
ELK

Asia Pacific Journals

seriously? The answer would be always 'Yes' and need to be addressed at the earliest possible.

The foot has already been set by the intellectual personalities to tackle the issue. The modern writers following the footsteps of their predecessors are awakening the writers in their writings to consider the issue as a major concern. India had witnessed quite a good number of social activists who fought against child marriages, sati sahagamanam etc. The fruits of their labour are certainly enjoyed by the women of today. Now many of the male and female writers are trying to address the problems of the day through their pens. The modern feminist writers like Shashi Deshpande, Manju Kapur, Bharathi Mukherjee etc have penned their novels on woman sufferings, domination of women by patriarchs and male domination to enlighten the present species. Sudha Murthy, M.Tech in Computer Science has also dealt with the problems faced by women in the software boomed world. Being the chairperson of Infosys, a teacher, and a philanthropist she has a deep insight into the emotions of people whom she meets every day as a part of her work. The two novels Mahashwetha
ELK Asia Pacific Journals - Special Issue ISBN: 978-81-930411-1-6

and Dollar Bahu undoubtedly show the woman in Karnataka, but in general are related to the entire country.

Life on earth is not a paradise, especially to women. Anupama, who moves heaven and earth to succeed in life, had many stumbling blocks. They were in the form of poverty, missing her mother when she was a one-year old baby, problems posed by her step-mother, poor father who was a school teacher, dominating aristocratic mother-in-law and sister-in-law and educated but heartless husband. Anupama,as the meaning suggests was a woman who could not be compared to others either in beauty or attitude. Dr.Anand, a genius falls in love with Anupama. She organizes a drama for raising funds to a charity. She sells the tickets to Dr.Anand, who was working with her uncle, her father's friend Dr.Desai. Dr.Anand hails from a blueblooded family, gives much importance to the physical beauty than the internal beauty. He was successful throughout his education and career and also expects his wife to be something special from others. His luck works out and he finds Anupama, who is rich physically and internally but poor in monetary pleasures. 
ELK

Asia Pacific Journals

Anand makes his mother Radhakka agree to the proposal. Radhakka, a widow of a contractor agreed to the alliance, with her own calculations in mind. She knew her son might marry an English woman as he was planning to do his advanced courses in medicine in England. If she agrees to the proposal people may think of her large heart by welcoming a poor girl into the family. Radhakka was also a beautiful lady with wealth and was blessed with an intelligent son like Anand and a beautiful daughter Girija. Money and material pleasures made them more compatible to degrade Anupama. Anupama had also liked Anand, when she first saw him in Dr.Desai's house. But she never revealed it keeping her financial status in mind.

Anupama's father was happy when he heard about Anand. One way the parents are more concerned about the wealth than humanity to send their daughters. Having no self-reliance, Anupama's father Shamanna made her daughter to agree the proposal. Observing their financial position, Radhakka said that she would bear the marriage expenses. Anupama was happy as her father was not going to be burdened by her marriage as she had two
ELK Asia Pacific Journals - Special Issue ISBN: 978-81-930411-1-6

step-sisters to get married. Sudha Murthy shows the pathetic situation of a poor father in front of a rich mother " Looking at Radhakka's ornaments, and Anand's Mercedes - symbols of world totally alien to him - Shamanna had grown so painfully aware of his limitations that he had not spoken at all." (37) Radhakka's decision was final and the marriage was performed to show the richness of Radhakka. She gave all sorts of jewellery and rich saris to Anupama, but could not give what the motherless child expected from her. Is poverty a big crime?

Anupama was happy for the next two months of her marriage. Anand started to England and Radhakka wanted Anupama to join Anand after the Lakshmi Puja, which would be after two months. Anupama was intelligent enough not to open her mouth huh she knew the illicit affairs of Girija. Her problems started from the day of Lakshmi puja when a hot live coal fell on her leg. She discovered the white patch on her leg and found it was Leukoderma or vitiligo from the dermatologist. She missed all her freedom as she was allowed to go out only in the car. She had to lie to Radhakka to make 
visits to the skin specialist. Unfortunately one day she was caught by Radhakka and her disease was revealed. They treated her like untouchable and send her to her father.

Anupama was blamed for hiding the disease and marrying Anand. He was the only person who knew the truth. A doctor by profession knows the internal emotional feelings of the patient but he just believed what his mother said ignoring the other side of the coin. Anupama wrote many letters expecting soothing words from him. He didn't pacify her nor met her when he came to India for his sister's marriage. How could a well-learned intellectual forget the promises he made at the time of their marriage before the sacred agni? Is it the age for him to rely on his mother's advice or take care of the wife, whom he has chosen to be a support throughout his life? Dr. Anand failed and made Anupama's life depressed. Poor Anupama worried for three years, suffering the humiliation of her stepmother, Sabakka as her daughters were not married because of her. She eventually hears from the villagers to where her father was transferred recently that Anand was going to marry again. She moves to Bombay to meet her friend Sumitra. She was cordially invited by Sumitra and Hari, her husband. She stays in their house for a year and Hari finds a job for her. She supports her family and maintains amicable relations with her colleagues. She finds the real man in Hari and moves to Dolly's house. She helps Anupama, as she helped Dolly a lot when she met with an accident. Dolly made Anupama to stay in her house as she left for Australia after her marriage. She also becomes a professor and once again directs plays on the stage.

Anupama meets with an accident and was treated by Dr. Vasant, a good humanitarian and his friend Satya. Satya was not as serious as Vasant and so was deceived in the hands of Dr.Divya, who leaves him in the dreams of dollars. Anupama helps him to recover from the shock as well as jaundice. Despite her problems, her willingness to help others and her positive smile made Vasanth to accept her as his life partner to fulfill his services of treating the poor in his village.

Meanwhile Anand realizes his mistake and searches for Anupama. After a long battle he finds her but Anupama rejects him. Anand's sincere change had no way melted Anupama, no more she was 
ELK

Asia Pacific Journals

the Mahaswetha struggling for her Pundarika, the play which brought them together. She wiped away her dream "Like Rohini to Chandra, like Lakshmi to Narayana, am I to him. Just as the creeper depends on a tree, emotionally I depend on him. I cannot live without him, for his sake, I am ready to renounce everything. Let society say anything it wishes. I do not care...' (7)to reality. Hers was true love, but Anand was charmed by her beauty. No doubt she was Mahaswetha as she lived in the role, but Anand was not her Pundarika. No more she wanted to search for a Pundarika, so she accepts even Vasant as her well-wisher, but not as a spouse. Though her step-mother didn't give her any support, she continues to support her family after her father's death. A lady with broken heart could spread melodies to all the members associated to her.

The second novel Dollar Bahu shows the senstitive relations in families. Life starts in a family and also ends in a family. The journey connects human and financial relations. It is unlucky that the present day relations are more financial than human. Dollar Bahu is in one-way a satire on ignorant people who are
ELK Asia Pacific Journals - Special Issue ISBN: 978-81-930411-1-6

fascinated towards the western culture and dollars. Vinuta, an outstanding singer meets Chandra Sekhar an employee from Bangalore deputed to look after the work at Dharwad in a train. Chandru has his own apprehensions about the new place and was helped by his brother Girish's friend. With his support he finds his stay as a paying guest in Vinuta's house. As a music lover he enjoys Vinuta's songs. He falls in love with her but never expresses it to her. Vinuta takes care of him when he had a fracture in his leg. She lives with her uncle and loves to take care of the house and the garden that her parents had left her.

Chandru is brought up in a lower middle class family who stays in Jayanagar in Bangalore. His father Shamanna was a school teacher; mother Gouramma an intelligent house-wife, Girish a simplemind brother and an ambitious sister Surabhi. He completed his graduation in engineering and joined in a local construction company and his hard-work gave him sporting chances. He was send to the dream land America from Dharwad. Gouramma was a good lady, but was crazy for wealth. She had an impact of the neighbouring women, who were as ignorant 
as she was not allowing Indian children mothers to participate in the conversation of American children mothers. She wanted to be like them. Chandru's departure to the fairy land sow seeds of greediness in her. Chandru worked hard in the land of opportunities living economically and learned computer courses after the day's work for which his company paid. Gouramma had built an up stair, brought about many modern changes in her life, not worrying about missing her son. Chandru was also equally fascinated by the captivating land and resumed his stay secretly by not informing to his former employers.

As Chandru was not sure of getting his green card, he told it would not be right for his parents to postpone Girish's marriage. Girish, who was working in a bank, met Vinuta in a bus. After her uncle's death, she had come from Dharwad and was staying in her aunt's house, working in a school. Girish knew she was working in the same school where his father was working. His generous father understood his son's love and arranged the alliance between Girish and Vinuta. Chandru had written a letter expressing his feelings to Vinuta after he had settled in America, but it was returned as Vinuta was not staying there. It's the destiny which is not in the hands of human beings; both brothers liked her but the brother who was not as good as the elder one could win the golden voiced girl. Chandru struggled in Nashville to get green card and returned to his own homeland after six years. As said by eminent personalities if you look at a thing from far it deceives our eyes, but when you look from near the ultimate truth comes out. Chandru was happy that he could satisfy his mother but his inner feelings were in one way buried. He was ready to marry Jamuna, a girl from a rich family whom his mother had chosen for him. He says, "Well, I plan to settle there. But one should be aware that life in America is lonely, as against life in India.”(49)

The entrance of the elder daughterin-law and her wealth made Gouramma to forget the realities of life. She was captivated by the dollar bahu and started humiliating Vinuta. She was the one who served her in-laws but was never rewarded. Naturally for a mother all her children are equal irrespective of the financial status, 
ELK

Asia Pacific Journals

but Gouramma had forgotten the simple issue by showing differences between her both daughter-in-laws. As human beings do we need to be reminded of such things by other family members? Yes, it was true in the case of Gouramma . Though Shamanna could understand the inherent qualities of her both daughter-inlaws, Gouramma turned a deaf ear to what he said. Can't a woman understand the other woman? Gouramma failed to realize the greatness of Vinuta. Pitifully American traditions jog her memory that Vinuta is the salt of the earth and Jamuna an intelligent shrewd.

Gouramma's agony could be clearly identified when she found Jamuna's attitude accidentally. When her friends ask her about her return to India, she makes crystal clear about her abhorrence of her inlaws, "No way! Here our husbands listen to us; we can eat, drink, dress and roam around the way we want. It is better to send some dollars as gifts than to settle in India. My father had clearly told me that he agreed to the proposal only because Chandru was in America, otherwise he would not have bothered. My parents had already judged these people before they
ELK Asia Pacific Journals - Special Issue

ISBN: 978-81-930411-1-6

accepted the proposal. My mother advised me to be nice, speak to them well, but keep them at a distance. That advice has helped." (129) what an eye-opening statement! Is it what a mother should teach her daughter while sending them to their in-law's house? Certainly it's not; they have to make their daughters treat their in-laws as their own parents. Yes, only parents can do it, because every individual listens only to his parents.

How could Vinuta win over her family, though she was not having parents to guide her and what made Jamuna to behave in such a way? It's only the power of money. In this context we are reminded of D.H.Lawrence's Poem Money Madness. He says "But it is not money we are terrified of, it is the collective moneymadness of mankind." (Pg.62) A small coin or notes which can be folded or handled are ruling a six feet man. Surabhi and Gouramma have become slaves in the hands of money. Girish, Shamana and Vinuta were not infected by the disease but Gouramma's greediness turned her daughter-in-law into a depressed condition. Shamanna cleverly reacted upon the 
ELK

Asia Pacific Journals

situation and send them away to a serene atmosphere where Girish, Vinuta and Harsha could lead a contented life free from the clutches of money. But Gouramma ultimately realizes her mistake and wanted to accept Vinuta.

In both the novels the protoganists were neck and neck in facing the hurdles. Both Anupama in Mahashweta and Vinuta in Dollar Bahu hail from poor families but imbibed with phenomenal characteristics. Though Anupama was from a poor family, she was always ready to help the poor by conducting charity shows. Vinuta never opened her mouth and with her docile attitude served her uncle's as well as her inlaw's family. As Anupama took care of Dr. Satya when he was suffering from jaundice, Vinuta nursed Chandru when he had a fracture. Both Anupama and Vinuta silently tolerated their predicaments without talking ill of their in-laws in public. Anupama could make out Girija's situation and Vinuta also identified the closeness of Surabhi with Gopinath. But unfortunately both of them were kept at arm's length as both the mother-in-laws had trusted their daughters than their daughter-in-laws.
ELK Asia Pacific Journals - Special Issue ISBN: 978-81-930411-1-6

Anupama lost her life as she was not having a father-in-law like Shamanna to stand on her side, but Vinuta was lucky at the end because she was free from the follies of her dollars digested mother-inlaw.

Sudha Murthy's knowledge is viewed in delineating the characters by making Anupama a good director in Sanskrit plays. Mahashweta and Dollar Bahu are good satirical works on the ignorance of innocent people still living in the peaceful parts of world. Though the country is globalised, people too are advanced in making money but not maintaining human relationships. Sudha Murthy gives a heart touching statement in Dollar Bahu through Shamanna " Nothing comes free, Vinu. And definitely not when it comes to financial help. This dollar may have transformed the lifestyles of some families, taken them from poverty to wealth, but it has also broken up some families and destroyed peace of mind. Very people have understood this." ( 139)

Modern feminist writers have clearly set the path for the younger 
ELK

Asia Pacific Journals

generations to taste the sweetness in their families. Readers irrespective of their age should read these two novels to lead a satisfied life. The characters of Anupama and Vinuta clearly show that family is made up of good human relations but not money.

\section{REFERENCES}

[1] Attridge, Derek (2004). The Singularity of Literature. New York: Routledge.

[2] Derrida, Jacques (1967a, 1978). Writing and Difference (Alan Bass, Trans.). London: Routledge.

[3] Mukherjee, Meenakshi. (1996) Realism and Reality: The novel and Society in India. New Delhi: Oxford University press.

[4] Murty, Sudha.(2007) Dollar Bahu, Penguin Books India: New Delhi.

[5] Murthy Sudha Mahashweta, Penguin Books India: New Delhi.

[6] Peter, Berry.(2002) Beginning Theory, An Introduction to literal and Cultural Theory, Manchester University Press, UK.
ELK Asia Pacific Journals - Special Issue ISBN: 978-81-930411-1-6

[7] Prudence, An Anthology for Degree Classes, Money Madness, Lawrence.D.H

[8] Sasikiran, SD. Sudha Murthy's Mahaswetha: Muse India, Issue 47: Jan-Feb 2013. 